\title{
Antecedents of customer switching intention in the Ghanaian telecommunications industry
}

\author{
Kwame Simpe Ofori ${ }^{a^{*}}$, Otu Larbi-Siaw ${ }^{\mathrm{b}}$ and John Agyekum Addae ${ }^{\mathrm{b}}$
}

${ }^{a}$ SMC University, Switzerland

${ }^{b}$ Ghana Technology University College, I.T. Business, Ghana

\begin{tabular}{l}
\hline C H R O N I C L E \\
\hline Article history: \\
Received June 5, 2015 \\
Received in revised format \\
August 162015 \\
Accepted November 232015 \\
Available online \\
November 23 2015 \\
\hline Keywords: \\
PL-SEM \\
Switching intention \\
Telecommunication \\
Satisfaction
\end{tabular}

\section{Introduction}

There has been a remarkable transformation in the telecommunication services worldwide, with these transformations brought about as result of technological innovations. Innovation in telecommunication technology has immensely influenced the development of mobile telecommunication services. Actually, the worldwide breakthrough of mobile technology is associated with the commercial introduction of digital technologies in the 1990s (Geetha \& Kumari, 2012). Telecommunications have been recognized as a crucial element in development. It has also been emphasized that telecommunication is one of the most convenient means of communicating and transacting business thus resulting in the accelerated growth of the market and industry. To enhance development, boosts investor confidence and promote business transactions there is the need for an effective telecommunications system. An effective telecommunication sector can be achieved by making the

* Corresponding author.

E-mail address: olsiaw@yahoo.co.uk (K. S. Ofori)

(C) 2015 Growing Science Ltd. All rights reserved. doi: 10.5267/j.ac.2015.11.006 
telecommunication market more flexible and open for consumers (Svendsen, 2013). Ghana's mobile telecom industry is highly oligopolistic. The industry is made up of six main operators namely MTN, Vodafone, TIGO, Airtel, GLO and Expresso, currently providing mobile telecom services to a variety of subscribers. There is high competition for customers in the industry hence the telecom companies adopt various strategies to gain a competitive advantage in the market. Firms are expanding their network to improve service quality so as to rope in more subscribers. Since firm's survival and growth are driven by customer loyalty, value and delivering quality service is imperative and an important goal of pursuit for each of the expanding mobile telecom networks.

In Ghana, various governments have adopted polices and measures aimed at making telecommunication services accessible to all the people in the country one of such reforms is the introduction of Mobile Number Portability. Mobile Number Portability enables users of one telecommunication network to migrate to another telecommunication network of their choice while retaining their original number if they are not satisfied with the service or products that the service provider offers. This reform in the telecommunication sector has been implemented in Ghana and all the six (6) telecommunication service providers offer this service under the directive of the National Communication Authority (NCA). The Mobile Number Portability has intensified competition between telecommunication companies by allowing subscribers to switch to any network of their preference at the cost of GH $\notin 1.00$ while maintaining the original mobile phone number (NCA, 2013).

The total costs of attracting a new customer/potential switcher from a competitor rapidly increase and substantially exceed the costs of retaining an existing customer (Kotler et al., 2003). Considering the unfavorable consequences of customer switching (e.g., decreased sales and market share, reduced profitability, and increased marketing costs) (Rust et al., 1995), service providers have largely concerned themselves with customer retention (Han and Back, 2008; Roos, 1999). Thus, maintaining their present market share has become the most critical task for network providers. In order to effectively retain their current customers, telcos must understand why customers switch from one service provider to another and identify the determining factors that affect customers' decision to stay or switch.

This study is therefore aimed at finding the driving factors that compels subscribers of telecommunication service companies to switch from their current service provider to another. With the main objective intended to identify the relationship between defined variables and intention to switch.

\section{Literature review and hypotheses}

Previous studies, mainly in marketing and consumer behavior, have explored service switching from the customer's perspective (Bansal \& Taylor, 1999). According to Sambandam and Lord (1995), service switching indicates a person's desire to replace/change his/her current service provider with another competitor. Many studies have examined and identified determinants of switching behaviors (Andreasen, 1985; Keaveney, 1995). Cronin and Taylor (1992) found that service quality/performance, satisfaction, and switching costs are most likely to inhibit customer switching. Similarly, Colgate and Lang (2001) and Keaveney (1995) identified service performance (i.e., core service and service encounter) and switching barriers (i.e., switching costs, relational investment, and lack of alternatives' attractiveness) as important inhibiting components of switching acts. It is not surprising, then, that many service firms seek to increase their service performance and satisfaction levels while dealing effectively with switching barriers to promote customer retention. The factors that influence the switching intention of mobile network subscribers can be categorized into two groups. These factors are the attributes of the mobile network and the characteristics of the mobile subscriber. Aydin and Özer (2005), Vyas and Raitani (2014), Quester and Lim (2003) and Kura et al. (2012) identified several factors relating to the attributes of the mobile network as critical to switching intention. The factors include: prices of mobile telecom services (prices for calls within network and calls outside network); 
service quality (that is network quality); range of products; customer care; discount, promotion and special offers on calls, text messages and multimedia messages; advertisement; and network size.

According to Aydin and Özer (2005), consumers take into account network size when choosing mobile operators, hence when a particular network has a wider coverage area it would compel subscribers to switch to that network. They argued that larger mobile networks have advantage over smaller networks in acquiring subscribers because of intra- network-call discounts and quality-signaling effect. This view is shared by (Nikbin et al., 2012). According to them, mobile network with larger subscriber base attracts more subscribers because with rising number of users subscribing to a network it becomes more attractive to other people to subscribe to the same network. On their part, Zhu et al. (2011) maintained that the larger the customer base of mobile network the greater the benefits from adoption. The benefits, they argued, relate to intra-network call discounts. Normally calls that terminate within the same network are relatively cheaper than calls terminating in another network. Thus customers are likely to pay less for mobile service when the network size is large.

\subsection{Antecedents of Intention to Switch}

Service switching, switching intention, customer loyalty, customer retention, and repurchase intention are all associated (Bansal \& Taylor, 1999; Han et al., 2009). While customer loyalty, retention, and repurchase intentions indicate favorable outcomes for the provider, service switching and switching intention imply unfavorable outcomes (Bansal \& Taylor, 1999; Han et al., 2009). In particular, the term "behavioral intention" includes both switching and rebuy intention (Keaveney, 1995). Whereas intention to switch refers to negative consequences, intention to repurchase indicates positive consequences. Oliver (1997) described behavioral intention as "stated likelihood to engage in a behavior" (p. 28). Similarly, switching intention in the present study indicates negative consequences for a service firm, referring to the affirmed likelihood of exchanging the current service provider with another. Below are the switching intention variables chosen for the empirical study.

\subsection{Interactional Justice (INTJ)}

Interactional justice suggests the extent of fairness in which service providers interact with and address failed customers. Most failed customers perceive interactional justice of a service recovery action when the offending service providers show their willing to interact with them respectfully, honestly and empathetically whilst trying to solve a problem and communicate with customers (Tax et al., 1998; Maxham \& Netemeyer, 2003; Wirtz \& Mattila, 2004). Interactional justice is generally assessed by reliability, clear explanation of the problem, sincerity, apologetic attitude, communication, politeness, respect, detailed attention to problems, willingness to hear complaints and willing to solve the problem (Smith et al., 1999; Wirtz \& Mattila, 2004).

\section{$H_{1}$ : There is a significant relationship between Interactional Justice and Satisfaction}

\subsection{Distributive Justice (DJ)}

Distributive justice relates to monetary compensation received by the failed customer. Most failed customers can perceive distributive justice of a recovery action after they have received a discount, coupons, refund, free giveaways or alternative goods as compensation from the offending service provider (Blodgett et al., 1997; Tax et al., 1998; Hoffman \& Kelley, 2000). Distributive justice can be assessed by customer perception of the fairness, equality, necessity and value of the compensation (Tax et al., 1998; Smith et al., 1999; Maxham \& Netemeyer, 2003; Wirtz \& Mattila, 2004).

\section{$H_{2}$ : There is a significant relationship between Distributive Justice and Satisfaction}

\subsection{Procedural Justice (PJ)}

Procedural justice which means customer perceptions of the recovery process recovery policies or rules. Failed customers can perceive procedural justice of a recovery action when the offending company 
admits the failure, attempts to fix its mistake timely and adapts its recovery strategy according to customer demands. Procedural justice can generally be assessed based on whether customers can freely express their opinions, recovery efficiency of the offending company, control the outcome of making complaints easy, flexible, instantaneous, transparency of the recovery process and suitability of the recovery action or policy (Tax et al., 1998; Smith et al., 1999; Maxham \& Netemeyer, 2003; Wirtz \& Mattila, 2004; Chebat \& Slusarczyk, 2005).

\section{H3: There is a significant relationship between Procedural Justice and Satisfaction}

\subsection{Informational Justice (INFJ)}

Informational justice "focuses on explanations provided to people that convey information about why procedures were used in a certain way or why outcomes were distributed in a certain fashion" (Colquitt et al., 2001). Informational justice conveys both inclusion and trustworthiness by reducing secrecy and dishonesty (Tyler \& Bies, 1990). It is therefore not surprising that informational justice predicted collective esteem. Indeed, collective esteem is closely linked to the salience of in-group membership (Luhtanen \& Crocker, 1992), and Tyler (1999) argued that providing important information signals acceptance by the in-group. Thus being "in the know" can, in fact, connote being "in the in-group.

\section{$H_{4}:$ There is a significant relationship between Informational Justice and Satisfaction}

\subsection{Service Quality (SERVQUAL)}

Service quality is considered a very important antecedent of switching behavior in the telecommunication industry (Aydin \& Özer 2005). According to them service quality is a critical factor that consumers in the telecommunication sector consider when subscribing to a service. This has the ability to increase the market share and the profitability of telecommunication service providers. A study also conducted by Vyas and Raitani (2014) in the banking industry in India revealed that poor service quality can lead to customers being less loyal to their bank. Hence a high level of service quality is required to prevent customers from switching to another bank. In a study conducted in the Nigerian banking industry by Kura et al. (2012), the authors found out that service quality has a significant relationship with the switching behavior of customers. Bennett and Barkensjo (2005), conducted a study involving service quality within charitable organizations in their provision of services using relationship quality and relationship marketing techniques. They found out that organizations that listened and interacted with their clients in manner to make them feel valued and part of the charity were considered as having exceptional relationship marketing skills.

\section{$H_{5 a}:$ There is a significant relationship between Service Quality and Satisfaction} $H_{5 b}$ : There is a significant relationship between Service Quality and Switching Intention

\subsection{Customer Satisfaction (SAT)}

Customer satisfaction is brought about when a customer is satisfied with the service or product of a service provider Customer satisfaction is brought about when a customer is satisfied with the service or product of a service provider (Aydin \& Özer 2005). The authors perceive customer satisfaction as final key determinant that customers consider when switching from a service provider. In order for organization to ensure long term success and also gain/protect market share they need to ensure they offer quality products and services to their customers. In order words when the general expectation of a customer is completely fulfilled it can lead to the customer repurchasing that particular product or service and giving a positive word-of-mouth to people about the company. This result is consistent with findings by Quester and Lim (2003) who found a positive association between customer satisfaction and switching behavior. They went on to say that satisfaction would come about based on a customer's experience with a product or service thus when they evaluate the quality of service based on how frequently they use or patronize that particular product or service. The authors went on further to say 
that satisfaction does not always guarantee loyalty on the part of consumers hence customers can be satisfied with a brand but not necessarily committed or loyal to that brand.

$H_{6 a}:$ There is a significant relationship between Satisfaction and Trust

$H_{6 b}$ : There is a significant relationship between Satisfaction and Loyalty

$H_{6 c}$ : There is a significant relationship between Satisfaction and Switching Intention

\subsection{Trust}

Trust is defined as when one party has confidence in an exchange partner's reliability and integrity (Morgan \& Hunt, 1994). Trust is a willingness to rely on an exchange partner in whom one has confidence in (Moorman et al., 1993). Also trust can be defined as users 'thoughts, feelings, emotions, or behaviors that occur when they feel that an agent can be relied upon to act in their best interest when they give up direct control (McCole, 2002). Trust is explained by satisfaction of mobile customer relationship marketing activities, which is evaluated by content differentiation, contact frequency and contents repetition. Thus, a study identified that customers' intention of continual usage can be achieved through trust (Lee et al., 2008).

These definitions highlight the importance of mutual confidence. The importance of trust is based on the potential use of the technology to increase information sharing. Trust increases the probability of a trading partner's willingness to expand the amount of information sharing and explore new mutually beneficial arrangements (Hart \& Saunders, 1997). As trust declines, people are increasingly unwilling to take risks and demand greater protections against the probability of betrayal. Doney and Cannon (1997) argue that trust consists of two aspects: perceived credibleness and benevolence. The square measure two levels of trust, in line with Rauyruen and Miller (2007). At the primary level, the client trusts one explicit sales representative whereas at the second level, the client trusts the establishment. Trust is a crucial mediating issue between client behavior before and when getting a product. It will cause long loyalty and strengthen the association between the two parties (Singh \& Sirdeshmukh, 2000). Like loyalty, trust may be a special psychological condition that may just occur in bound relationships. In previous analysis, trust has been conceptualized as antecedent of satisfaction (e.g., Palvia, 2009).

\section{H7a: There is a significant relationship between Trust and Loyalty}

\subsection{Customer Loyalty}

Customer loyalty, according to Walsh et al. (2008), is when a customer becomes faithful to a brand upon the delivery of a service or product. Fraering and Minor (2013) stated that highly loyal customers tend not to defect to competitors. The authors inferred that customer loyalty is synonymous with repeat customers and customers that offer good ratings and testimonial about their current service provider. A similar study conducted by Ou et al. (2011) found out that customer loyalty programs had a partially significant positive impact on loyalty. They went on further to explain that a customer is loyal to a service provider irrespective of whether that service provider offers better conditions, products or services hence loyal customers should be rewarded because they enable service providers make profit. Some of the reward measures they can put in place is the provision of loyalty packages to loyal customers. This would prevent customer dissatisfaction and make loyal customers feel appreciated hence less likely to switch service providers. When customers are highly committed, they are more likely to recommend their service provider to other people hence a fruitful long-term relationship will co-exist between the customers and the service provider.

\section{H8: There is a significant relationship between Loyalty and Switching Intention}




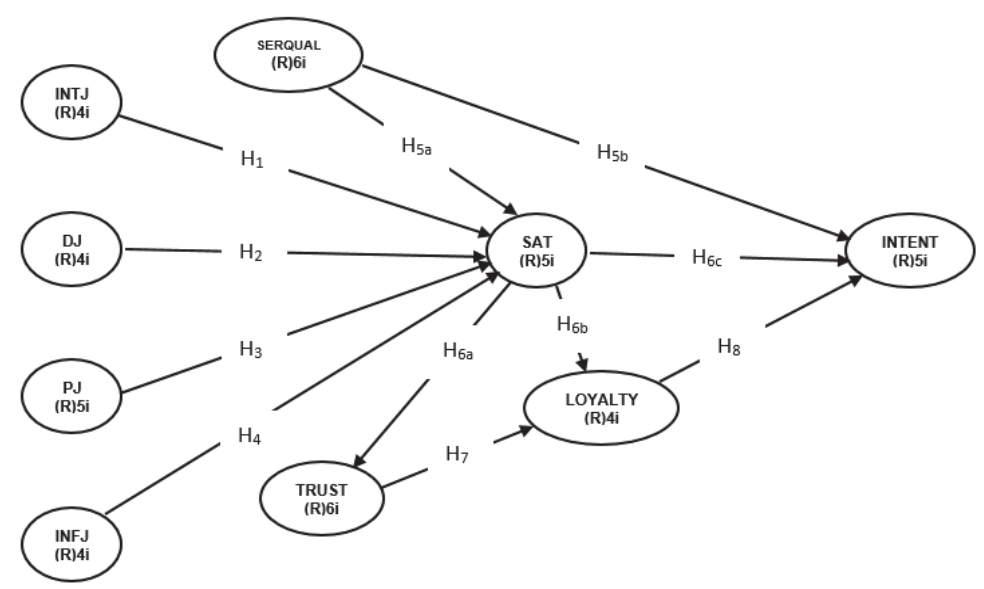

Fig. 1. Conceptual Framework

\section{Methodology}

\subsection{Measurement Instrument}

The measurement items for the latent variables used in this study were drawn from previous studies and the questions were reworded to fit the Mobile service environment. Items for Distributive Justice and Interactional Justice were derived from Homburg and Fürst (2005), Procedural Justice and Informational Justice from Ambrose et al. (2007) and Colquitt (2001). Loyalty and Service Quality were both derived from Aydin and Özer (2005). Five items for measuring Satisfaction were adopted and adapted from Vázquez-Casielles et al. (2009). Six items for measuring Trust were adopted from Aydin et al. (2005) and Morgan and Hunt (1994). All measurement items are presented and measured using a 5-point Likert scale anchored between 1 (Strongly Disagree) and 5 (Strongly Agree). Our measurement instrument had 44 items in total.

\subsection{Sample and data collection}

Before conducting the survey, the survey instrument was reviewed by three experts. The modified questionnaire was pilot tested on 56 students with all constructs showing satisfactory levels of reliability and validity. Empirical data was collected via a paper-based survey from students in Ghana Technology University College. Students were deemed appropriate as respondents for this survey for two reasons. First university students constitute an important proportion of mobile phone subscribers. Secondly young adults have greater knowledge about communication services than older adults. A total number of 430 questionnaires were distributed and 264 were returned representing a response rate of about $61 \%$. However, 29 questionnaire were discarded due to a significant number of missing fields. In all 235 responses were anlayzed for the purpose of the research.

\subsection{Data Analysis Tools}

Data collected was analyzed using the Partial Least Square approach to structural equation modelling (PLS-SEM) on WarpPLS (Kock, 2013). Structural Equation Modelling is a second generation statistical technique used to test causal relationships between latent variables. Two approaches of SEM exist (Hair et al., 2014); the more stringent Covariance-Based SEM and the soft modelling approach PLS-SEM (Wold, 1982) or the Variance Based approach. The authors chose PLS-SEM since it does not require multivariate normality and also because it lends itself to modelling with small sample size (Henseler et al., 2009). 


\section{Results and analysis}

\subsection{Measurement Model}

Results for the measurement model is presented in Tables 1 and 2. The measurement model is assessed based on reliability, convergent validity and discriminant validity. In evaluating indicator reliability the factor loadings of each indicator should be above 0.708 (Hair et al., 2014), from Table 1 signify that, indicator reliability is largely achieved since all the factor loadings except that for SI1 (0.698) and SQ6 (0.667) are above 0.708. For constructs to be reliable Cronbach's alpha and composite reliability values should be greater or equal to 0.7 (Cronbach, 1951; Nunnally \& Bernstein, (1994); from Table 2 it is evident that all constructs have values greater than 0.7 indicating that the scales have internal consistency.

Table 1

Loading and Cross Loadings

\begin{tabular}{|c|c|c|c|c|c|c|c|c|c|c|}
\hline & & INT & SERVQ & TRUST & SAT & LOYAL & DJ & PJ & INFJ & INTJ \\
\hline \multirow{5}{*}{$\begin{array}{l}\text { SWITCHING } \\
\text { INTENTION }\end{array}$} & SI1 & 0.698 & -0.198 & -0.164 & -0.220 & -0.293 & -0.153 & -0.199 & -0.146 & -0.268 \\
\hline & SI2 & 0.765 & -0.226 & -0.143 & -0.187 & -0.277 & -0.129 & -0.136 & -0.088 & -0.107 \\
\hline & SI3 & 0.854 & -0.311 & -0.283 & -0.326 & -0.425 & -0.296 & -0.286 & -0.247 & -0.239 \\
\hline & SI4 & 0.810 & -0.194 & -0.197 & -0.127 & -0.231 & -0.186 & -0.180 & -0.117 & -0.108 \\
\hline & SI5 & 0.814 & -0.294 & -0.248 & -0.177 & -0.261 & -0.194 & -0.243 & -0.174 & -0.091 \\
\hline \multirow{6}{*}{$\begin{array}{l}\text { SERVICE } \\
\text { QUALITY }\end{array}$} & SQ1 & -0.222 & 0.792 & 0.427 & 0.427 & 0.382 & 0.274 & 0.300 & 0.331 & 0.278 \\
\hline & SQ2 & -0.220 & 0.814 & 0.480 & 0.413 & 0.381 & 0.306 & 0.307 & 0.344 & 0.258 \\
\hline & SQ3 & -0.327 & 0.782 & 0.543 & 0.466 & 0.425 & 0.418 & 0.482 & 0.441 & 0.442 \\
\hline & SQ4 & -0.209 & 0.797 & 0.446 & 0.509 & 0.455 & 0.423 & 0.374 & 0.396 & 0.323 \\
\hline & SQ5 & -0.249 & 0.810 & 0.605 & 0.518 & 0.488 & 0.442 & 0.469 & 0.447 & 0.495 \\
\hline & SQ6 & -0.234 & 0.667 & 0.535 & 0.453 & 0.455 & 0.348 & 0.429 & 0.400 & 0.523 \\
\hline \multirow{6}{*}{ TRUST } & T1 & -0.202 & 0.561 & 0.785 & 0.538 & 0.517 & 0.460 & 0.489 & 0.488 & 0.447 \\
\hline & $\mathrm{T} 2$ & -0.211 & 0.568 & 0.838 & 0.571 & 0.550 & 0.493 & 0.491 & 0.500 & 0.449 \\
\hline & $\mathrm{T} 3$ & -0.188 & 0.569 & 0.850 & 0.563 & 0.558 & 0.525 & 0.500 & 0.502 & 0.475 \\
\hline & $\mathrm{T} 4$ & -0.209 & 0.430 & 0.822 & 0.546 & 0.468 & 0.531 & 0.409 & 0.452 & 0.433 \\
\hline & T5 & -0.290 & 0.543 & 0.780 & 0.615 & 0.592 & 0.578 & 0.585 & 0.550 & 0.521 \\
\hline & $\mathrm{T} 6$ & -0.181 & 0.453 & 0.749 & 0.523 & 0.463 & 0.551 & 0.554 & 0.475 & 0.537 \\
\hline \multirow{5}{*}{$\begin{array}{c}\text { CUSTOMER } \\
\text { SATISFACTION }\end{array}$} & CS1 & -0.273 & 0.557 & 0.655 & 0.875 & 0.673 & 0.698 & 0.555 & 0.707 & 0.487 \\
\hline & $\mathrm{CS} 2$ & -0.285 & 0.544 & 0.602 & 0.901 & 0.679 & 0.692 & 0.547 & 0.701 & 0.498 \\
\hline & $\mathrm{CS} 3$ & -0.231 & 0.487 & 0.603 & 0.879 & 0.665 & 0.688 & 0.547 & 0.659 & 0.466 \\
\hline & CS4 & -0.194 & 0.520 & 0.613 & 0.886 & 0.650 & 0.698 & 0.517 & 0.679 & 0.510 \\
\hline & CS5 & -0.178 & 0.520 & 0.596 & 0.874 & 0.601 & 0.670 & 0.514 & 0.615 & 0.457 \\
\hline \multirow{4}{*}{$\begin{array}{l}\text { CUSTOMER } \\
\text { LOYALTY }\end{array}$} & CL1 & -0.346 & 0.501 & 0.579 & 0.702 & 0.909 & 0.508 & 0.577 & 0.592 & 0.570 \\
\hline & CL2 & -0.323 & 0.498 & 0.554 & 0.611 & 0.893 & 0.513 & 0.532 & 0.579 & 0.572 \\
\hline & CL3 & -0.346 & 0.543 & 0.662 & 0.727 & 0.924 & 0.629 & 0.704 & 0.666 & 0.615 \\
\hline & CL4 & -0.335 & 0.425 & 0.532 & 0.602 & 0.845 & 0.487 & 0.516 & 0.529 & 0.472 \\
\hline \multirow{4}{*}{$\begin{array}{l}\text { DISTRIBUTIVE } \\
\text { JUSTICE }\end{array}$} & DJ1 & -0.199 & 0.410 & 0.525 & 0.683 & 0.509 & 0.860 & 0.487 & 0.565 & 0.358 \\
\hline & DJ2 & -0.210 & 0.422 & 0.574 & 0.733 & 0.573 & 0.883 & 0.531 & 0.619 & 0.443 \\
\hline & DJ3 & -0.210 & 0.402 & 0.600 & 0.643 & 0.482 & 0.873 & 0.576 & 0.599 & 0.444 \\
\hline & DJ4 & -0.239 & 0.417 & 0.566 & 0.666 & 0.528 & 0.875 & 0.541 & 0.605 & 0.346 \\
\hline \multirow{5}{*}{$\begin{array}{l}\text { PROCEDURAL } \\
\text { JUSTICE }\end{array}$} & PJ1 & -0.232 & 0.367 & 0.504 & 0.492 & 0.495 & 0.534 & 0.815 & 0.547 & 0.458 \\
\hline & PJ2 & -0.228 & 0.467 & 0.516 & 0.514 & 0.576 & 0.541 & 0.868 & 0.527 & 0.535 \\
\hline & PJ3 & -0.141 & 0.390 & 0.557 & 0.523 & 0.561 & 0.537 & 0.865 & 0.548 & 0.562 \\
\hline & PJ4 & -0.224 & 0.454 & 0.534 & 0.522 & 0.571 & 0.497 & 0.867 & 0.535 & 0.674 \\
\hline & PJ5 & -0.310 & 0.461 & 0.550 & 0.534 & 0.577 & 0.498 & 0.843 & 0.565 & 0.624 \\
\hline \multirow{4}{*}{$\begin{array}{l}\text { INFORMATIONAL } \\
\text { JUSTICE }\end{array}$} & IJ1 & -0.148 & 0.458 & 0.568 & 0.658 & 0.624 & 0.637 & 0.609 & 0.872 & 0.558 \\
\hline & IFJ2 & -0.217 & 0.423 & 0.546 & 0.681 & 0.629 & 0.581 & 0.556 & 0.886 & 0.549 \\
\hline & IFJ3 & -0.153 & 0.456 & 0.543 & 0.700 & 0.564 & 0.612 & 0.562 & 0.902 & 0.508 \\
\hline & IFJ4 & -0.186 & 0.456 & 0.531 & 0.673 & 0.550 & 0.609 & 0.550 & 0.904 & 0.480 \\
\hline \multirow{5}{*}{$\begin{array}{l}\text { INTERACTIONAL } \\
\text { JUSTICE }\end{array}$} & ITJ1 & -0.129 & 0.504 & 0.547 & 0.499 & 0.568 & 0.452 & 0.588 & 0.566 & 0.849 \\
\hline & ITJ2 & -0.185 & 0.405 & 0.497 & 0.473 & 0.513 & 0.417 & 0.580 & 0.517 & 0.884 \\
\hline & ITJ3 & -0.162 & 0.344 & 0.468 & 0.426 & 0.481 & 0.338 & 0.508 & 0.453 & 0.874 \\
\hline & ITJ4 & -0.188 & 0.444 & 0.539 & 0.497 & 0.576 & 0.380 & 0.619 & 0.522 & 0.864 \\
\hline & ITJ5 & -0.218 & 0.437 & 0.517 & 0.488 & 0.580 & 0.395 & 0.621 & 0.496 & 0.874 \\
\hline
\end{tabular}

Note: INT - Switching Intention, SERVQ - Service Quality, SAT - Satisfaction, DJ - Distributive Justice, PJ - Procedural Justice, INFJ - Informational Justice, INTJ - Interactional Justice

Convergent validity was tested using Average variance extracted (AVE). For constructs to exhibit convergent validity the AVE should be higher than 0.50 so that the latent variables explain more than 
half of the variance of its indicators (Fornell \& Larcker, 1981; Henseler, Ringle, \& Sinkovics, 2009). Table 2 below can be seen to show that all constructs meet this criterion.

Finally, to assess discriminant validity the following guidelines were used: (1) The Fornel- Larker criterion; which states that the Average Variance Extracted (AVE) of each latent construct should be greater than the highest squared correlations between any other construct (Fornell \& Larcker, 1981) (2) The loadings of each indicator should be greater than all its cross loadings (Chin, 1998; Götz, LiehrGobbers, \& Krafft, 2010; Henseler et al., 2009). In Table 2, we can see that the square root of AVE (shown on the diagonal of the correlation matrix in bold) for each construct is higher than the correlation between that construct and any other construct. Alternatively from Table 1 it can be seen that item loadings for each construct is greater than the cross loadings further indicating discriminant validity of the measurement model. Based on these results we can says that the measurement models result indicate that the model has good internal consistency, indicator reliability, convergent validity and discriminant validity. Hence, the constructs from our model is statistically distinct and can be used to test the structural model.

Table 2

Correlation Matrix with Square root of AVE

\begin{tabular}{|c|c|c|c|c|c|c|c|c|c|c|c|c|}
\hline & INTENT & SERVQUA & TRUST & SAT & LOYAL & DJ & PJ & INFJ & INTJ & CA & CR & AVE \\
\hline INTENT & 0.79 & & & & & & & & & 0.848 & 0.892 & 0.624 \\
\hline SERVQUA & -0.312 & 0.779 & & & & & & & & 0.869 & 0.902 & 0.606 \\
\hline TRUST & -0.265 & 0.648 & 0.805 & & & & & & & 0.891 & 0.917 & 0.648 \\
\hline SAT & -0.263 & 0.596 & 0.695 & 0.883 & & & & & & 0.929 & 0.946 & 0.780 \\
\hline LOYALTY & -0.378 & 0.552 & 0.652 & 0.74 & 0.893 & & & & & 0.915 & 0.940 & 0.798 \\
\hline DJ & -0.246 & 0.473 & 0.649 & 0.78 & 0.599 & 0.873 & & & & 0.896 & 0.928 & 0.762 \\
\hline PJ & -0.266 & 0.503 & 0.625 & 0.607 & 0.653 & 0.612 & 0.852 & & & 0.905 & 0.930 & 0.726 \\
\hline INFJ & -0.198 & 0.503 & 0.614 & 0.761 & 0.663 & 0.684 & 0.639 & 0.891 & & 0.913 & 0.939 & 0.794 \\
\hline INTJ & -0.203 & 0.49 & 0.591 & 0.548 & 0.625 & 0.456 & 0.671 & 0.587 & 0.869 & 0.919 & 0.939 & 0.755 \\
\hline
\end{tabular}

Note: Square roots of average variances extracted (AVEs) shown on diagonal

\subsection{Structural Model Assessment}

Once the measurement model quality has been confirmed to be acceptable the structural model can then be assessed. The structural model determines whether the structural relations in the model tested are meaningful (Sarstedt, Ringle, Smith, Reams, \& Hair, 2014). The quality of the structural model was assessed by the ability to predict endogenous construct and this was achieved by using the coefficient of determination $\mathrm{R}^{2}$ and cross-validated redundancy $\mathrm{Q}^{2}$ (Sarstedt et al., 2014; Urbach \& Ahlemann, 2010). In order to test the hypothesized paths the size, the sign and the significance of the path coefficients were assessed.

The $\mathrm{R}^{2}$ is the measure of the variance of each of the endogenous construct explained by or model and it measures the predictive power of the constructs (Chin, 2010; Sarstedt et al., 2014). The $\mathrm{R}^{2}$ measure ranges from 0 to 1 with values closer to 1 indicating greater degree of predictive power.

For variance explained by the endogenous variables to have practical and statistical significance it is recommended that $R^{2}$ values be $\geq 0.10$ (Lee et al., 2011). As a guidelines for assessing $R^{2}, 0.75,0.50$ and 0.25 represent substantial, moderate and weak respectively (Hair et al., 2014; Hair et al., 2011).

The path significance levels were estimated using a bootstrap with 5000 resamples (Hair et al., 2014). The results for the structural model is summarized in Table 3 and explained as follows: Distributive Justice $(\beta=0.435, P<0.001)$, Informational Justice $(\beta=0.360, P<0.001)$, and Servqual $(\beta=0.18$, $\mathrm{P}=0.003$ ), were found to be significant predictors of satisfaction providing support for $\mathrm{H}_{2}, \mathrm{H}_{4}$ and $\mathrm{H}_{5}$. 
The results further showed that Distributive Justice had the most effect on satisfaction. Interactional Justice and Procedural Justice were however found not to be significant. The model explains $77 \%$ of the variation in Satisfaction $\left(\mathrm{R}^{2}=0.77\right)$.

The path between Satisfaction and Loyalty was also found to be significant $(\beta=0.56, p<0.001)$, in other words if Satisfaction increased by one standardized unit Loyalty increased by 0.56 standardized units ceteris paribus. Trust was also found to be a significant predictor of Loyalty $(\beta=0.271, \mathrm{p}<0.001)$, providing support for $\mathrm{H}_{7}$. Jointly Trust and Satisfaction explained $59 \%\left(\mathrm{R}^{2}=0.59\right)$ of the variation in Loyalty. In predicting Trust, Satisfaction $(\beta=0.700, p<0.001)$ was found to be statistically significant thereby confirming $\mathrm{H}_{6 \mathrm{~b}}$. The model explained $48 \%\left(\mathrm{R}^{2}=0.48\right)$ of the variation in Trust.

Service Quality $(\beta=-0.210, p<0.001)$, Loyalty $(\beta=-0.284, p<0.001)$, were found to be significant in explaining Intention to Switch, thus supporting hypothesis $\mathrm{H}_{5 b}$ and $\mathrm{H}_{8}$ respectively.

Table 3

Results of Hypothesis Testing

\begin{tabular}{llccc}
\hline Hypothesis & Hypothesized Path & Path Coefficient & P-value & Result \\
\hline $\mathrm{H}_{1}$ & INTJ $\rightarrow$ SAT & 0.060 & 0.18 & Not Supported \\
$\mathrm{H}_{2}$ & DJ $\rightarrow$ SAT & 0.435 & $<0.001 * * *$ & Supported \\
$\mathrm{H}_{3}$ & PJ $\rightarrow$ SAT & 0.012 & 0.425 & Not Supported \\
$\mathrm{H}_{4}$ & INFJ $\rightarrow$ SAT & 0.360 & $<0.001 * * *$ & Supported \\
$\mathrm{H}_{5 \mathrm{a}}$ & SERQUAL $\rightarrow$ SAT & 0.180 & $0.003 * *$ & Supported \\
$\mathrm{H}_{5 \mathrm{~b}}$ & SERVQUAL $\rightarrow$ INTENT & -0.210 & $<0.001 * * *$ & Supported \\
$\mathrm{H}_{6 \mathrm{a}}$ & SAT $\rightarrow$ TRUST & 0.700 & $<0.001 * * *$ & Supported \\
$\mathrm{H}_{6 \mathrm{~b}}$ & SAT $\rightarrow$ LOYALTY & 0.560 & $<0.001 * * *$ & Supported \\
$\mathrm{H}_{6 \mathrm{c}}$ & SAT $\rightarrow$ INTENT & 0.010 & 0.410 & Not Supported \\
$\mathrm{H}_{7}$ & TRUST $\rightarrow$ LOYALTY & 0.271 & $<0.001 * * *$ & Supported \\
$\mathrm{H}_{8}$ & LOYALTY $\rightarrow$ INTENT & -0.284 & $<0.001 * * *$ & Supported \\
\hline$* * *$ significant at $\mathrm{p}=0.001 * *$ significant at $=0.01 *$ significant at $\mathrm{p}=0.05$ & & &
\end{tabular}

The negative signs on the path coefficients (fig.2) indicate that as service quality and loyalty increased the intention to switch decreased. Based on the data collected, the direct path between Satisfaction and Intention to Switch was seen not to be significant. However the indirect path through Loyalty was found to be significant. Moreover our model explains $\mathbf{1 7 \%}\left(\mathrm{R}^{2}=0.17\right)$ of the variation in Intention to Switch.

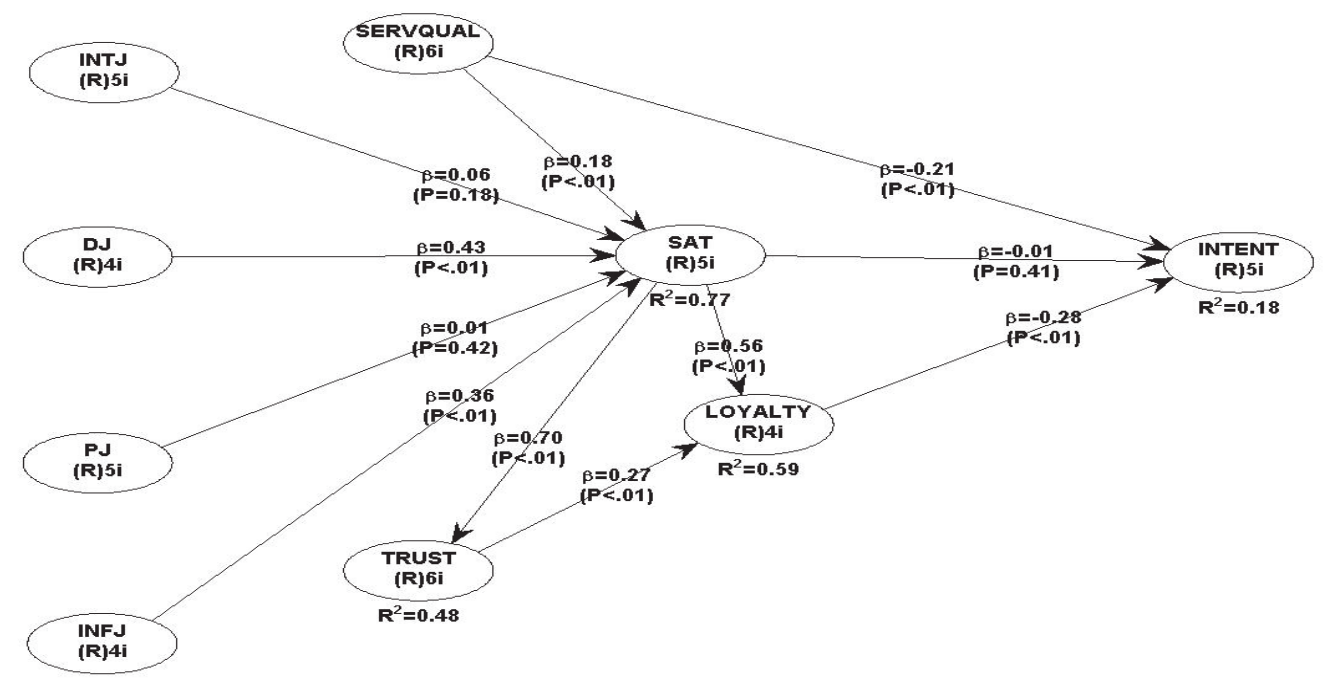

Fig. 2. Structural Evaluation Model showing Path Coefficient and $\mathrm{R}^{2}$ 
In all, out of the 11 hypotheses formulated, 8 are confirmed by the data we collected. Figure 2 and table 3 summarize the empirical results of the research hypotheses.

\section{Table 4}

Model fit and quality indices

\begin{tabular}{ll}
\hline Index & Value/ Thresholds \\
\hline Average R Squared & $0.506^{* * *}$ \\
Average Path Coefficient & $0.279^{* * *}$ \\
Average block VIF & $2.686 /$ acceptable if $<=5$, ideally $<=3.3$ \\
Tanenhaus GoF & $0.604 /$ small $>=0.1$, medium $>=0.25$, large $>=0.36$ \\
\hline${ }^{* * *}$ significant at $\mathrm{p}=0.001$ &
\end{tabular}

WarpPLS 4.0 (Kock, 2013) calculates model fit indices namely Average R squared (ARS), Average Path Coefficient and Average Variance Inflation Factor and Tanenhaus GoF, Table 4 summarizes these indices. According to Kock, (2013) APC and ARS should be significant at 5\% whiles AVIF should be less than 5. From Table 4 it can be see that both ARS and APC are significant at $0.1 \%$.and AVIF is 1.554 showing evidence of good fit. Overall fit of the model was assessed with the Tenenhaus GoF, defined as the Geometric mean of the average communality and average $\mathrm{R}^{2}$ for endogenous variables (Tenenhaus, Amato, \& Vinzi, 2004; Tenenhaus, Vinzi, Chatelin, \& Lauro, 2005; Wetzels, OdekerkenSchröder, \& van Oppen, 2009). Guidelines suggest that GoF of 0.1, 0.25 and 0.36 represent small, medium and large fit respectively (Kock, 2013; Wetzels et al., 2009). For our model we obtained a GoF of 0.604 compellingly greater than the cut-off of 0.36 for large fit. Based on these result we conclude that the proposed model has good fit with the data and measures well.

\section{Conclusion and recommendations}

In most industries and businesses a significant asset to all successful businesses are repeat customers highlighting how essential this is within the telecommunications industry in Ghana. The essential need to retain customers becomes essential in this study as measures can be devised in understanding customer switching intentions and preventing them in order to avert loss of revenue and market share.

On the basis of the responses from the 400 respondents, results of the empirical study expose the models path coefficient explains $\mathbf{7 7 \%}$ of the variation in Satisfaction $\left(\mathrm{R}^{2}=0.77\right)$; explains $\mathbf{5 9 \%}\left(\mathrm{R}^{2}=0.59\right)$ of the variation in Loyalty; explains $\mathbf{4 8 \%}\left(\mathrm{R}^{2}=0.48\right)$ of the variation in Trust and explains $\mathbf{1 7 \%}\left(\mathrm{R}^{2}=\right.$ $0.17)$ of the variation in Intention to Switch.

Out of the 11 hypotheses formulated, 8 are confirmed to be significant by the empirical results of the research with the inference explained.

$\mathrm{H}_{1}$ and $\mathrm{H}_{3}$ show an insignificant relationship between Interactional, Procedural Justice and Satisfaction whereas $\mathrm{H}_{2}, \mathrm{H}_{4}$ and $\mathrm{H}_{5}$ show a significant relationship between Distributive Justice, Informational Justice, Service Quality and Satisfaction respectively.

$\mathrm{H}_{5 \mathrm{~b}}$ indicates a significant relationship between Service Quality and Switching Intention. Service quality is considered a very important antecedent of switching behaviour in the telecommunication industry (Aydin \& Özer, 2005). According to them service quality is a critical factor that consumers in the telecommunication sector consider when subscribing to a service. It can be inferred that this variable is an important factor that causes switching in customers. Network service providers will be wise to ensure good service/network quality as it has the ability to increase the market share and the profitability of telecommunication service providers and vice versa. 
$\mathrm{H}_{6 \mathrm{a}}$ shows a significant relationship between Satisfaction and Trust with $\mathrm{H}_{6 \mathrm{~b}}$ displaying a significant relationship between Satisfaction and Loyalty. $\mathrm{H}_{6 \mathrm{c}}$ showed an insignificant relationship between Satisfaction and Switching Intention. $\mathrm{H}_{7}$ display a significant relationship between Trust and Loyalty whereas $\mathrm{H}_{8}$ indicates a significant relationship between Loyalty and Switching Intention. Fraering \& Minor (2013) stated that highly loyal customers tend not to defect to competitors. The author's infered that customer loyalty is synonymous with repeat customers and customers that offer good ratings and testimonial about their current service provider. Loyal customers should be rewarded by service providers with loyalty packages and schemes as this prevents them from defecting or switching to other competitors when there is satisfaction and appreciation.

This study has revealed some areas for future study in telecommunications. Firstly, future research can look at studying longitudinal data to see how time affects the relationships between the variables. In another research, researchers could look at a national level study so as to be able to generalise the study findings in a broader context and also make it applicable to other sectors as well. The Moderating effects of knowledge of Mobile Number Portability on the path between Switching Cost and Switching Intention could also be explored.

\section{References}

Ambrose, M., Hess, R. L., \& Ganesan, S. (2007). The relationship between justice and attitudes: An examination of justice effects on event and system-related attitudes. Organizational Behavior and Human Decision Processes, 103(1), 21-36.

Andreasen, A. R. (1985). Consumer responses to dissatisfaction in loose monopolies. Journal of Consumer Research, 12(2), 135-141.

Aydin, S., \& Özer, G. (2005). The analysis of antecedents of customer loyalty in the Turkish mobile telecommunication market. European Journal of Marketing, 39(7/8), 910-925.

Aydin, S., \& Özer, G. (2005). The analysis of antecedents of customer loyalty in the Turkish mobile telecommunication market. European Journal of Marketing, 39(7/8), 910-925.

Bansal, H. S., \& Taylor, S. F. (1999). The service provider switching model (spsm) a model of consumer switching behavior in the services industry. Journal of Service Research, 2(2), 200-218.

Bennett, R., \& Barkensjo, A. (2005). Relationship quality, relationship marketing, and client perceptions of the levels of service quality of charitable organisations. International Journal of Service Industry Management, 16(1), 81-106.

Blodgett, J. G., Hill, D. J., \& Tax, S. S. (1997). The effects of distributive, procedural, and interactional justice on postcomplaint behavior. Journal of Retailing, 73(2), 185-210.

Colgate, M., \& Lang, B. (2001). Switching barriers in consumer markets: an investigation of the financial services industry. Journal of Consumer Marketing, 18(4), 332-347.

Colquitt, J. A., Conlon, D. E., Wesson, M. J., Porter, C. O., \& Ng, K. Y. (2001). Justice at the millennium: a meta-analytic review of 25 years of organizational justice research. Journal of Applied Psychology, 86(3), 425-445.

Chebat, J. C., \& Slusarczyk, W. (2005). How emotions mediate the effects of perceived justice on loyalty in service recovery situations: an empirical study.Journal of Business Research, 58(5), 664673.

Chin, W. W. (1998). The partial least squares approach to structural equation modeling. Modern Methods for Business Research, 295(2), 295-336.

Chin, W. W. (2010). How to write up and report PLS analyses. In Handbook of Partial Least Squares (pp. 665-690).

Cronbach, L. J. (1951). Coefficient alpha and the internal structure of tests.Psychometrika, 16(3), 297 334.

Cronin Jr, J. J., \& Taylor, S. A. (1992). Measuring service quality: a reexamination and extension. The Journal of Marketing, 56(3), 55-68. 
Doney, P. M., \& Cannon, J. P. (1997). An examination of the nature of trust in buyer-seller relationships. The Journal of Marketing, 61(2), 35-51.

Fornell, C., \& Larcker, D. F. (1981). Evaluating structural equation models with unobservable variables and measurements error. Journal of Marketing Research, 18(1), 39-50.

Fraering, M., \& Minor, M. S. (2013). Beyond loyalty: customer satisfaction, loyalty, and fortitude. Journal of Services Marketing, 27(4), 334-344.

Geetha, M., \& Abitha Kumari, J. (2012). Analysis of churn behavior of consumers in Indian telecom sector. Journal of Indian Business Research,4(1), 24-35.

Götz, O., Liehr-Gobbers, K., \& Krafft, M. (2010). Evaluation of Structural Equation Models Using the Partial Least Squares (PLS) Approach. In Handbook of Partial Least Squares (pp. 691-711).

Hair, J. F., Ringle, C. M., \& Sarstedt, M. (2011). PLS-SEM: Indeed a Silver Bullet. The Journal of Marketing Theory and Practice, 19(2), 139-152.

Hair, J. F. J., Hult, G. T. M., Ringle, C., \& Sarstedt, M. (2014). A Primer on Partial Least Squares Structural Equation Modeling (PLS-SEM). Thousand Oaks: Sage Publications.

Han, H., \& Back, K. J. (2008). Relationships among image congruence, consumption emotions, and customer loyalty in the lodging industry. Journal of Hospitality \& Tourism Research, 32(4), 467490.

Han, H., Back, K. J., \& Barrett, B. (2009). Influencing factors on restaurant customers' revisit intention: The roles of emotions and switching barriers. International Journal of Hospitality Management, 28(4), 563-572.

Hart, P., \& Saunders, C. (1997). Power and trust: Critical factors in the adoption and use of electronic data interchange. Organization science, 8(1), 23-42.

Henseler, J., Ringle, C. M., \& Sinkovics, R. (2009). The use of partial least squares path modeling in international marketing. Advances in International Marketing, 20, 277-319.

Hoffman, K. D., \& Kelley, S. W. (2000). Perceived justice needs and recovery evaluation: a contingency approach. European Journal of Marketing, 34(3/4), 418-433.

Homburg, C., \& Fürst, A. (2005). How Organizational Complaint Handling Drives Customer Loyalty: An Analysis of the Mechanistic and the Organic Approach. Journal of Marketing, 69(3), 95-114.

Keaveney, S. M. (1995). Customer switching behavior in service industries: An exploratory study. The Journal of Marketing, 59(2), 71-82.

Kock, N. (2013). WarpPLS 4.0 User Manual. Laredo, Texas: ScriptWarp Systems.

Kotler, P. (2003). Marketing Management, 11th ed., Prentice-Hall, Englewood Cliffs, NJ.

Klemperer, P. (1987). Markets with consumer switching costs. Quarterly Journal of Economics, 102(2), 375-394.

Kura, K. M., Mat, N. K. N., Gorondutse, H., Magaji, A. M., \& Usman, A. Y. (2012, June). Determining the Antecedents of Customer Switching Behavior in Nigerian Banking Industry. In 1st Global Conference for Academic Research (GCAR 2012).

Lee, D. I., Sohn, C., \& Lee, H. (2008). The role of satisfaction and trust in mobile CRM activities. International Journal of Electronic Customer Relationship Management, 2(2), 101-119.

Lee, L., Petter, S., Fayard, D., \& Robinson, S. (2011). On the use of partial least squares path modeling in accounting research. International Journal of Accounting Information Systems, 12(4), 305-328.

Luhtanen, R., \& Crocker, J. (1992). A collective self-esteem scale: Self-evaluation of one's social identity. Personality and Social Psychology Bulletin, 18(3), 302-318.

Maxham III, J. G., \& Netemeyer, R. G. (2003). Firms reap what they sow: the effects of shared values and perceived organizational justice on customers' evaluations of complaint handling. Journal of Marketing, 67(1), 46-62.

McCole, P. (2002). The role of trust for electronic commerce in services. International Journal of Contemporary Hospitality Management, 14(2), 81-87.

Moorman, C., Deshpande, R., \& Zaltman, G. (1993). Factors affecting trust in market research relationships. The Journal of Marketing, 57(1), 81-101.

Morgan, R. M., \& Hunt, S. D. (1994). The Commitment-Trust Theory of Relationship Marketing. Journal of Marketing, 58(3), 20-38. 
NCA-Subscriber Base Information (2013). Overview of the Industry Statistics (Online). Available at: http://www.nca.org.gh/overviewofindustrystatistics.html [Accessed: 18 August, 2015].

Nikbin, D., Ismail, I., Marimuthu, M., \& Armesh, H. (2012). Perceived justice in service recovery and switching intention: Evidence from Malaysian mobile telecommunication industry. Management Research Review, 35(3/4), 309-325.

Nunnally, J., \& Bernstein, I. (1994). Psychometric Theory (3rd ed.). New York: McGraw-Hill.

Oliver, R. L. (1997). Satisfaction: A Behavioural Perspective on the Consumer. Boston: Irwin McGraw-Hill.

Ou, W. M., Shih, C. M., Chen, C. Y., \& Wang, K. C. (2011). Relationships among customer loyalty programs, service quality, relationship quality and loyalty: An empirical study. Chinese Management Studies, 5(2), 194-206.

Palvia, P. (2009). The role of trust in e-commerce relational exchange: A unified model. Information \& management, 46(4), 213-220.

Quester, P., \& Lin Lim, A. (2003). Product involvement/brand loyalty: is there a link? Journal of product \& brand management, 12(1), 22-38.

Rauyruen, P., \& Miller, K. E. (2007). Relationship quality as a predictor of B2B customer loyalty. Journal of Business Research, 60(1), 21-31.

Roos, A. J. (1999). Does ownership or competition matter? The effects of telecommunication reform in network expansion and efficiency. Journal of Regulatory Economics, 15(1), 65-92.

Rust, R. T., Zahorik, A. J., \& Keiningham, T. L. (1995). Return on quality (ROQ): Making service quality financially accountable. The Journal of Marketing, 59(2), 58-70.

Sambandam, R., \& Lord, K. R. (1995). Switching behavior in automobile markets: a consideration-sets model. Journal of the Academy of Marketing Science, 23(1), 57-65.

Sarstedt, M., Ringle, C. M., Smith, D., Reams, R., \& Hair, J. F. (2014). Partial least squares structural equation modeling (PLS-SEM): A useful tool for family business researchers. Journal of Family Business Strategy, 5(1), 105-115.

Singh, J., \& Sirdeshmukh, D. (2000). Agency and trust mechanisms in consumer satisfaction and loyalty judgments. Journal of the Academy of marketing Science, 28(1), 150-167.

Smith, A. K., Bolton, R. N., \& Wagner, J. (1999). A model of customer satisfaction with service encounters involving failure and recovery. Journal of Marketing Research, 36(3), 356-372.

Svendsen, G. B., \& Prebensen, N. K. (2013). The effect of brand on churn in the telecommunications sector. European Journal of Marketing, 47(8), 1177-1189.

Tax, S. S., Brown, S. W., \& Chandrashekaran, M. (1998). Customer evaluations of service complaint experiences: implications for relationship marketing. The Journal of Marketing, 62(2), 60-76.

Tyler, T. R., \& Bies, R. J. (1990). Beyond formal procedures: The interpersonal context of procedural justice. Applied Social Psychology and Organizational Settings, 77, 98.

Tenenhaus, M., Amato, S., \& Esposito Vinzi, V. (2004, June). A global goodness-of-fit index for PLS structural equation modelling. In Proceedings of the XLII SIS scientific meeting (Vol. 1, pp. 739742). CLEUP Padova.

Tenenhaus, M., Vinzi, V. E., Chatelin, Y. M., \& Lauro, C. (2005). PLS path modeling. Computational Statistics \& Data Analysis, 48(1), 159-205.

Urbach, N., \& Ahlemann, F. (2010). Structural equation modeling in information systems research using partial least squares. Journal of Information Technology Theory and Application, 11(2), 5-40.

Vázquez-Casielles, R., Suárez-Álvarez, L., \& Del Río-Lanza, A. B. (2009). Customer satisfaction and switching barriers: Effects on repurchase intentions, positive recommendations, and price tolerance. Journal of Applied Social Psychology, 39(10), 2275-2302.

Vyas, V., \& Raitani, S. (2014). Drivers of customers' switching behaviour in Indian banking industry. International Journal of Bank Marketing, 32(4), 321-342.

Walsh, G., Evanschitzky, H., \& Wunderlich, M. (2008). Identification and analysis of moderator variables: investigating the customer satisfaction-loyalty link. European Journal of Marketing, 42(9/10), 977-1004. 
Wetzels, M., Odekerken-Schröder, G., \& van Oppen, C. (2009). Using PLS path modeling for assessing hierarchical construct models: Guidelines and Empirical Illustration. MIS Quarterly, 33(1), 177195.

Wold, H. (1982). Soft modelling: the basic design and some extensions.Systems Under Indirect Observation, Part II, 36-37.

Wirtz, J., \& Mattila, A. S. (2004). Consumer responses to compensation, speed of recovery and apology after a service failure. International Journal of Service Industry Management, 15(2), 150-166.

Zhu, G., Ao, S., \& Dai, J. (2011). Estimating the switching costs in wireless telecommunication market. Nankai Business Review International, 2(2), 213-236. 